\title{
Apple scenario of India: An economic analysis
}

\author{
JYOTI L. ZIRMIRE, VILAS S. KULKARNI AND BALACHANDRA K. NAIK
}

Received : 08.05.2017; Revised : 15.08.2017; Accepted : 29.08.2017

\begin{abstract}
The present work was taken upto investigate the policies which will help in increasing the production and satisfying local and global demand of apple. Preliminarily compound annual growth rate analysis was taken up for the period 2006-07 to 2015-16 and it was found that the area, production and productivity increased at the rate of $2.69,4.13$ and 1.36 per cent per annum, respectively. The instability was very less with respect to area, production and productivity of apples in the country. It was found that the import of apple by India in terms of quantity as well as value increased at the rate of 1.18 and 4.81 per cent per annum. With respect to imports, the instability was very less in terms of quantity as compared to that of its value. While in case of the Indian apple exports in terms of quantity and value registered negative growth rates $(-8.54 \%$ and $-15.01 \%$ per annum). Export of apples showed higher level of instability in terms of both quantity and value. It is estimated that the imports of apples will be increasing year by year and by 2019-20, the expected import of apples would be around 2,11,305 metric tons. The estimated export of apples using compound growth rates would be around 17,560 metric tons during 2016-17 and would gradually decrease and would reach around 13,433 metric tons by 2019-20. It was concluded that although there is positive and significant growth in area, production and productivity of apples in India, there is need to take a concerted efforts in terms of improving the quality of the product.
\end{abstract}

KEY WORDS : Apple, Production, Instability indices, Export, Import

How to cite this paper : Zirmire, Jyoti L., Kulkarni, Vilas S. and Naik, Balachandra K. (2017). Apple scenario of India: An economic analysis. Internat. J. Com. \& Bus. Manage, 10(2) : 116-120, DOI: 10.15740/HAS/IJCBM/10.2/116-120.

Email: vilasdharwad@rediffmail.com; bpkoti@yahoo.com 